\title{
Occurrence and Molecular Identification of Azoxystrobin-Resistant Colletotrichum cereale Isolates from Golf Course Putting Greens in the Southern United States
}

Joseph R. Young, former graduate research assistant, Mississippi State University, currently Department of Horticulture, University of Arkansas, Fayetteville 72701; Maria Tomaso-Peterson, Department of Entomology and Plant Pathology, Mississippi State University, Mississippi State 39762; Lane P. Tredway, Department of Plant Pathology, North Carolina State University, Raleigh 27695; and Karla de la Cerda, Environmental Biology, University of Guelph, Ontario, N1G2W1 Canada

\begin{abstract}
Young, J. R., Tomaso-Peterson, M., Tredway, L. P., and de la Cerda, K. 2010. Occurrence and molecular identification of azoxystrobin-resistant Colletotrichum cereale isolates from golf course putting greens in the southern United States. Plant Dis. 94:751-757.

Turfgrass anthracnose, caused by Colletotrichum cereale ( $\equiv$ C. graminicola), has become a common disease of creeping bentgrass and annual bluegrass putting greens throughout the southern United States. Strobilurin (QoI) fungicides such as azoxystrobin are single-site modeof-action fungicides applied to control $C$. cereale. In vitro bioassays with azoxystrobin at 0.031 and $8 \mu \mathrm{g} / \mathrm{ml}$ incorporated into agar were performed to evaluate the sensitivity of 175 isolates collected from symptomatic turfgrasses in Alabama, Mississippi, North Carolina, Tennessee, and Virginia. Three sensitivity levels were identified among C. cereale isolates. Resistant, intermediately resistant, and sensitive isolates were characterized by percent relative growth based on the controls with means of 81,23 , and $4 \%$, respectively, on media containing azoxystrobin at 8 $\mu \mathrm{g} / \mathrm{ml}$. The molecular mechanism of resistance was determined by comparing amino acid sequences of the cytochrome b protein. Compared with sensitive isolates, $C$. cereale isolates exhibiting QoI resistance had a G143A substitution, whereas isolates expressing intermediate resistance had a F129L substitution. C. cereale isolates displaying azoxystrobin resistance in vitro were not controlled by QoI fungicides in a field evaluation. The dominance of QoI-resistant $C$. cereale isolates identified in this study indicates a shift to resistant populations on highly managed golf course putting greens.
\end{abstract}

Anthracnose, incited by Colletotrichum cereale Manns sensu lato Crouch, Clarke, \& Hillman ( $\equiv$ C. graminicola (Ces.) G.W. Wils.) (11), has become a common and destructive disease of creeping bentgrass (Agrostis stolonifera L.) and annual bluegrass (Poa annua L.) putting greens in the transition zone and throughout the southern United States (33). Generally, anthracnose occurs on creeping bentgrass putting greens during the summer and early autumn as the turf becomes physiologically weakened from heat stress, predisposing the foliar portion of the plant to infection by $C$. cereale. The symptoms of anthracnose foliar blight on creeping bentgrass putting greens appear as yellow to bronze irregularly shaped areas that may coalesce and are often associated with a loss of turf

Corresponding author: M. Tomaso-Peterson E-mail: mariat@pss.msstate.edu

Approved for publication as Mississippi Agricultural and Forestry Experimental Station Journal Article No. J-11707.

Accepted for publication 3 March 2010.

doi:10.1094/PDIS-94-6-0751

(C) 2010 The American Phytopathological Society density (33). Moreover, symptoms can be exacerbated on heat-stressed creeping bentgrass. Similarly, $C$. cereale infects annual bluegrass putting greens, causing foliar blight or basal rot symptoms further described by Smiley et al. (24).

Fungicides are applied in a preventive manner to creeping bentgrass and annual bluegrass putting greens on a biweekly basis from April to October to manage many turf pathogens, including $C$. cereale. A proactive, preventive fungicide program that includes biochemical (single- or multisite) and topical (contact or penetrant) mode-of-action (MOA) rotations is an effective approach for anthracnose management. Strobilurin, phosphate, or demethylation inhibitor fungicides applied alone or tank mixed with a contact fungicide have proven to be an effective control $(8,30)$. Environmental conditions may favor disease development, thus requiring curative applications that include singlesite MOA fungicides due to their efficacy at low doses and their fungitoxic effect post application $(9,21,31)$.

In the 1970s, research was initiated on a by-product of the fungus Strobilurus tenacellus (Pers.) Singer exhibiting fungicidal properties $(4,23)$. The by-product, referred to as strobilurin, targeted the mitochondrial electron transport chain at the Qo center (Qo inhibitor or QoI) of cytochrome $b_{1}$ (35). The first synthetically produced strobilurin (QoI) fungicide was released in Germany in 1996 under the common name azoxystrobin, a broad-spectrum fungicide labeled for several plant diseases (23).

Shortly after QoI fungicides (QoIs) were introduced to the turf market in the mid1990 s, fungicide resistance was documented $(1,2,12,28)$. Population shifts from QoI-sensitive to QoI-resistant Pyricularia grisea (Cooke) Sacc. (gray leaf spot) infecting perennial ryegrass (Lolium perenne L.) occurred rapidly under heavy disease pressure. Reduced sensitivity of $P$. grisea to azoxystrobin was initially observed in vitro (28). Subsequent molecular analysis identified an amino acid substitution from glycine $(\mathrm{G})$ to alanine $(\mathrm{A})$ at position 143 (G143A) in the cytochrome b protein of isolates with the greatest resistance to azoxystrobin. Intermediate resistance was also observed in isolates with an amino acid substitution from phenylalanine (F) to leucine (L) at position 129 (F129L) (16). Since these initial findings, QoI resistance has been detected in $C$. cereale isolated from annual bluegrass in two separate studies $(2,29)$. C. cereale isolates collected from locations where QoIs were applied were not inhibited when exposed to azoxystrobin at 8 or $10 \mu \mathrm{g} / \mathrm{ml}(2,29)$. In addition, isolate responses were similar for trifloxystrobin and pyraclostrobin, indicating cross resistance among QoIs $(2,29)$. Molecular techniques confirmed in vitro results with all resistant isolates having the G143A substitution (2,29).

Based on the frequency of QoI fungicide applications for management of anthracnose throughout the transition zone and southern United States, and the increased anecdotal and documented evidence of resistance to this class of fungicides in $C$. cereale populations $(2,6,7,10,17-19,25$, 26,29), studies were established to determine whether $C$. cereale isolates causing anthracnose on creeping bentgrass and annual bluegrass putting greens in the eastern transition zone and southern United States were resistant to azoxystrobin. The objectives of this research were to determine the sensitivity of $C$. cereale isolates to azoxystrobin using in 
vitro bioassays, obtain nucleotide sequences of the cytochrome $b$ gene to identify point mutations resulting in amino acid substitutions, and evaluate the efficacy of QoI fungicides in a creeping bentgrass putting green artificially inoculated with $C$. cereale isolates exhibiting azoxystrobin resistance based on in vitro bioassays.

\section{MATERIALS AND METHODS}

Isolate collection. $C$. cereale was isolated from creeping bentgrass plants exhibiting symptoms of anthracnose or heat stress during summer 2006 and 2007 in Alabama and Mississippi (Table 1; 32). Individual plants exhibiting signs of $C$. cereale (acervuli and setae) were surface disinfested by rinsing in $70 \%$ ethanol for 1 min followed by an agitated rinse in $0.6 \%$ sodium hypochlorite solution for $90 \mathrm{~s}$, rinsed with sterile distilled water three times, and air dried on sterile filter paper in a laminar flow hood $(3,15)$. One hundred plants (shoots and roots) from each location were transferred (five per plate) onto a modified potato dextrose agar (mPDA; $6 \mathrm{~g}$ of Difco PDA and $15 \mathrm{~g}$ of agar per liter amended with $100 \mathrm{mg}$ each of chloramphenicol and streptomycin sulfate). The plants were incubated at room temperature (approximately $22^{\circ} \mathrm{C}$ ) with 24-h fluorescent light for 4 to 7 days. Monoconidial isolates of $C$. cereale were placed in $-20^{\circ} \mathrm{C}$ for long-term storage on air-dried, sterilized glass fiber filter paper (Fisher Scientific, Pittsburg, PA; 32). Sen-

Table 1. Colletotrichum cereale isolates from various hosts and locations throughout the United States and the frequency of phenotypic responses observed with azoxystrobin at $8 \mu \mathrm{g} / \mathrm{ml}$

\begin{tabular}{llcccr}
\hline & & & \multicolumn{3}{c}{ Phenotypic response } \\
\cline { 3 - 6 } Location & \multicolumn{1}{c}{ Host } & No. of isolates & Sens. $^{\mathbf{v}}$ & Int. $^{\mathbf{w}}$ & Resist. $^{\mathbf{x}}$ \\
\hline West Point, MS & Creeping bentgrass & 30 & 0 & 0 & 30 \\
Birmingham, AL & Creeping bentgrass & 5 & 0 & 0 & 5 \\
Birmingham, AL & Creeping bentgrass & 6 & 0 & 0 & 6 \\
Sylacauga, AL & Creeping bentgrass & 2 & 0 & 0 & 2 \\
West Point, MS & Creeping bentgrass & 6 & 0 & 0 & 6 \\
West Point, MS & Creeping bentgrass & 10 & 0 & 0 & 10 \\
Birmingham, AL & Creeping bentgrass & 1 & 0 & 0 & 1 \\
Inverness, AL & Creeping bentgrass & 6 & 0 & 0 & 6 \\
Olive Branch, MS & Creeping bentgrass & 2 & 0 & 0 & 2 \\
Tupelo, MS & Creeping bentgrass & 12 & 0 & 0 & 12 \\
Tupelo, MS & Creeping bentgrass & 1 & 0 & 0 & 1 \\
Pennsylvania & Annual bluegrass & $2 \mathrm{y}$ & 2 & 0 & 0 \\
Temecula, CA & Annual bluegrass & $17^{\mathrm{z}}$ & 17 & 0 & 0 \\
Starkville, MS & Tall fescue & 4 & 4 & 0 & 0 \\
Leland, NC & Creeping bentgrass & 11 & 0 & 0 & 11 \\
Charlotte, NC & Creeping bentgrass & 2 & 0 & 0 & 2 \\
Sanford, NC & Creeping bentgrass & 3 & 0 & 0 & 3 \\
Monroe, NC & Creeping bentgrass & 7 & 0 & 0 & 7 \\
Virginia Beach, VA & Creeping bentgrass & 5 & 0 & 0 & 5 \\
Gatlinburg, TN & Creeping bentgrass & 6 & 0 & 0 & 6 \\
Blowing Rock, NC & Annual bluegrass & 36 & 0 & 9 & 27 \\
Asheville, NC & Annual bluegrass & 1 & 1 & 0 & 0 \\
\hline
\end{tabular}

${ }^{v}$ Sensitive: number of isolates from a location exhibiting growth inhibition with azoxystrobin at 8 $\mu \mathrm{g} / \mathrm{ml}$ and approximately $50 \%$ growth inhibition at $0.031 \mu \mathrm{g} / \mathrm{ml}$.

" Intermediate: number of isolates from a location exhibiting minimal growth inhibition with azoxystrobin at $0.031 \mu \mathrm{g} / \mathrm{ml}$ but significant growth inhibition at $8 \mu \mathrm{g} / \mathrm{ml}$.

$\mathrm{x}$ Resistant: number of isolates from a location exhibiting minimal growth inhibition with azoxystrobin at $8 \mu \mathrm{g} / \mathrm{ml}$.

${ }^{y}$ C. cereale isolates courtesy of G. Olaya, Syngenta Crop Protection, Inc., Vero Beach, FL (2).

${ }^{z}$ C. cereale isolates courtesy of F. Wong, University of California, Riverside (31). was added to 1 liter m-PDA to deliver the desired azoxystrobin concentration. A nonamended control (acetone at $1 \mathrm{ml} /$ liter of m-PDA) was included as a treatment. All treatments were amended with salicylhydroxamic acid (SHAM) at $100 \mu \mathrm{g} / \mathrm{ml}$ to inhibit the alternative oxidase pathway $(1,2,19,28,29,35)$.

Infested filter paper was placed on $\mathrm{m}$ PDA to initiate mycelial growth. A seed plate culture was obtained for each isolate by transferring mycelium to fresh m-PDA. A 5-mm-diameter hyphal plug was removed from the margin of a 10-day-old $C$. cereale culture and placed, mycelium-side down, in the center of azoxystrobinamended or nonamended media. Isolates were incubated at room temperature (approximately $22^{\circ} \mathrm{C}$ ) in the dark for 6 days, after which three equidistant colony growth diameter measurements were recorded.

Data analysis. Percent relative growth was calculated by dividing the average radial colony growth on azoxystrobinamended media by the average radial colony growth on nonamended media and multiplied by 100 . An arbitrarily selected sample of $C$. cereale isolates $(n=40)$, exhibiting variations in percent relative growth and later characterized molecularly, were included in the statistical analysis. Percent relative growth values from the bioassays were arcsine transformed using SAS (version 9.1; SAS Institute, Cary, NC) and analyzed using PROC GLIMMIX. Treatment means were separated by least square means $(P=0.05)$. Following analysis, values were back transformed and reported as percent relative growth. Relative growth of $C$. cereale isolates collected from Alabama and Mississippi (single isolate evaluated per plate, replicated twice) were analyzed separately from isolates from North Carolina, Tennessee, and Virginia (single isolate evaluated per plate, replicated three times) due to the in vitro sensitivity evaluations being conducted in separate laboratories.

The effective concentration required to achieve $50 \%$ inhibition of mycelial growth on azoxystrobin-amended media $\left(\mathrm{EC}_{50}\right)$ was calculated for $C$. cereale isolates $(n=45)$ collected from locations in Alabama and Mississippi and those originating from California and Pennsylvania $(2,32)$. Percent relative growth for an individual isolate at eight azoxystrobin concentrations ranging from $4.9 \times 10^{-4}$ to $8 \mu \mathrm{g} / \mathrm{ml}$ was subjected to the regression procedure (PROC REG) in SAS to obtain the intercept $\left(b_{0}\right)$ and slope $\left(b_{1}\right)$. The $\mathrm{EC}_{50}$ value $(\mu \mathrm{g} / \mathrm{ml})$ for each isolate was calculated using the equation:

$$
\operatorname{azoxystrobin}_{50 \%}=e\left[\left(50-b_{0}\right) / b_{1}\right]
$$

All bioassays were conducted twice and data were pooled for individual isolates.

Characterization of cytochrome b gene sequences. The $C$. cereale isolates in- 
cluded in the statistical analysis from Alabama, Mississippi, and California characterized as resistant $(n=20)$ or sensitive ( $n$ $=5$ ) based on azoxystrobin in vitro bioassays were sequenced to confirm the molecular mechanisms of azoxystrobin resistance (12). Fresh mycelium was harvested from a 21-day-old culture grown on mPDA and lyophilized prior to RNA extraction with the RNeasy Mini Kit (Qiagen, Valencia, CA). The AccessQuick RT-PCR System (Promega Corp., Madison, WI) was used to create cDNA from RNA. Extracted RNA $(1 \mu \mathrm{l})$ was incorporated with reagents, including primers $\mathrm{C} 1 \quad\left(5^{\prime} \mathrm{gga}\right.$ agaggtatgtactacggttca $\left.3^{\prime}\right)$ and $\mathrm{C} 2\left(5^{\prime}\right.$ acg ctaaaacccctcaaac $3^{\prime}$ ) previously described by Wong et al. (29), and incubated in a MyCycler Thermal Cycler (Bio-Rad, Hercules, CA) at $45^{\circ} \mathrm{C}$ for $45 \mathrm{~min}$. The cytochrome $b$ gene was amplified with the GoTaq PCR Core System (Promega Corp.) and $5 \mu \mathrm{l}$ of cDNA (32). Polymerase chain reactions (PCRs) were performed in the thermal cycler with the following program: $95^{\circ} \mathrm{C}$ for $3 \mathrm{~min} ; 30$ cycles of $95^{\circ} \mathrm{C}$ for $30 \mathrm{~s}$, $51^{\circ} \mathrm{C}$ for $45 \mathrm{~s}$, and $72^{\circ} \mathrm{C}$ for $2 \mathrm{~min}$; followed by an extension cycle at $72^{\circ} \mathrm{C}$ for 5 min and a $10^{\circ} \mathrm{C}$ holding temperature. The amplicon was visualized using electrophoresis in a $1.5 \%$ agarose gel to ensure its desired size of 219 bp. Amplicons corresponding to the size were purified with ExoSAP-IT (USB Corp., Cleveland, OH) according to the manufacturer's instructions. The purified amplicon was cloned according to protocol with the pGEM-T Easy Vector System (Promega Corp.) and plasmids were purified with the Qiaprep Spin Miniprep Kit (Qiagen).

Purified plasmids were prepared for sequencing according to the manufacturer's instructions with the DTCS Quick Start Kit (Beckman and Coulter, Fullerton, CA). Nucleotide sequencing was performed at the Life Sciences and Biotechnology Institute at Mississippi State University using the Beckman CEQ 8000 DNA Analysis System (Beckman and Coulter). DNASTAR Lasergene Software (DNASTAR Inc., Madison, WI) was used to trim, translate, align, and interpret nucleotide sequences.

The cytochrome $b$ gene of representative C. cereale isolates from North Carolina, Tennessee, and Virginia was sequenced using the following protocol. RNA was extracted from lyophilized mycelium using the protocol for plant tissue from Purescript (Gentra Systems Inc., Minneapolis, $\mathrm{MN}$ ). Reverse-transcription (RT)-PCR was performed in same-tube reactions using the Thermoscript RT-PCR System (Invitrogen, Carlsbad, CA) and the primers previously described (29). The optimal thermal cycling program for reverse transcriptase was performed, and PCR amplification was conducted using the thermal cycling program previously described. Electrophoresis was performed for all amplicons in $1.5 \%$ agarose gel to ensure that the product cor- responded to the expected size of $219 \mathrm{bp}$. These amplicons were sequenced directly at the Duke University DNA Sequencing Facility in Durham, NC.

The sequence data obtained from all isolates were compared with the original $C$. cereale cytochrome $b$ sequence (GenBank accession number AY285743) to determine

Table 2. Treatments and application rates of strobilurin (QoI) and other fungicides for control of anthracnose on a creeping bentgrass putting green inoculated with azoxystrobin-resistant Colletotrichum cereale isolates in North Carolina, $2006^{\mathrm{x}}$

\begin{tabular}{ll}
\hline Fungicide $^{\mathbf{y}}$ & Rate (kg or liters of product/ha) \\
\hline Thiophanate-methyl & 12.6 liters \\
Phosphoric acid & 17.6 liters \\
Chlorothalonil/thiophanate-methyl $^{\mathrm{z}}$ & $17.6 \mathrm{~kg}$ \\
Chlorothalonil/thiophanate-methyl $^{\mathrm{z}}+$ phosphoric acid & $17.6 \mathrm{~kg}+17.6$ liters \\
Azoxystrobin & $0.61 \mathrm{~kg}$ \\
Fosetyl-Al & $12.2 \mathrm{~kg}$ \\
Propiconazole & $3.18 \mathrm{liters}$ \\
Fluoxastrobin & 0.57 liter \\
Fluoxastrobin & 1.14 liter \\
Fluoxastrobin + propiconazole & 0.57 liter +3.18 liters \\
Fluoxastrobin + chlorothalonil & 0.57 liter $+5.5 \mathrm{~kg}$ \\
Fluoxastrobin + polyoxin-D & 0.57 liter $+6.1 \mathrm{~kg}$ \\
Fluoxastrobin + propiconazole + potassium phosphate & 0.57 liter +3.18 liters +12.7 liters \\
Fluoxastrobin followed by propiconazole & 0.57 liter followed by 3.18 liters \\
Fluoxastrobin followed by polyoxin-D & 0.57 liter followed by $6.11 \mathrm{~kg}$ \\
Fosetyl-Al + chlorothalonil & $12.2 \mathrm{~kg}+9.8 \mathrm{~kg}$ \\
Chlorothalonil & $9.8 \mathrm{~kg}$ \\
Phosphoric acid + chlorothalonil & 17.6 liters $+9.8 \mathrm{~kg}$ \\
Pyraclostrobin & $1.5 \mathrm{~kg}$ \\
Control (water) & \\
\hline
\end{tabular}

${ }^{\mathrm{x}}$ Colletotrichum cereale inoculum $\left(9 \times 10^{3}\right.$ conidia/ml $)$ applied as a foliar suspension to the creeping bentgrass the evening of 25 May 2006; $\mathrm{CO}_{2}$-powered boom sprayer at $276 \mathrm{kPa} ; 8004$ flat fan nozzles, calibrated to deliver water at 814 liters/ha; irrigated with $2.5 \mathrm{~mm}$ of water.

y Treatments applied in water equivalent to 814 liters/ha; 14-day spray interval; application dates 29 June, 13 and 27 July, and 10 and 23 August 2006.

${ }^{\mathrm{z}}$ Prepackaged fungicide.

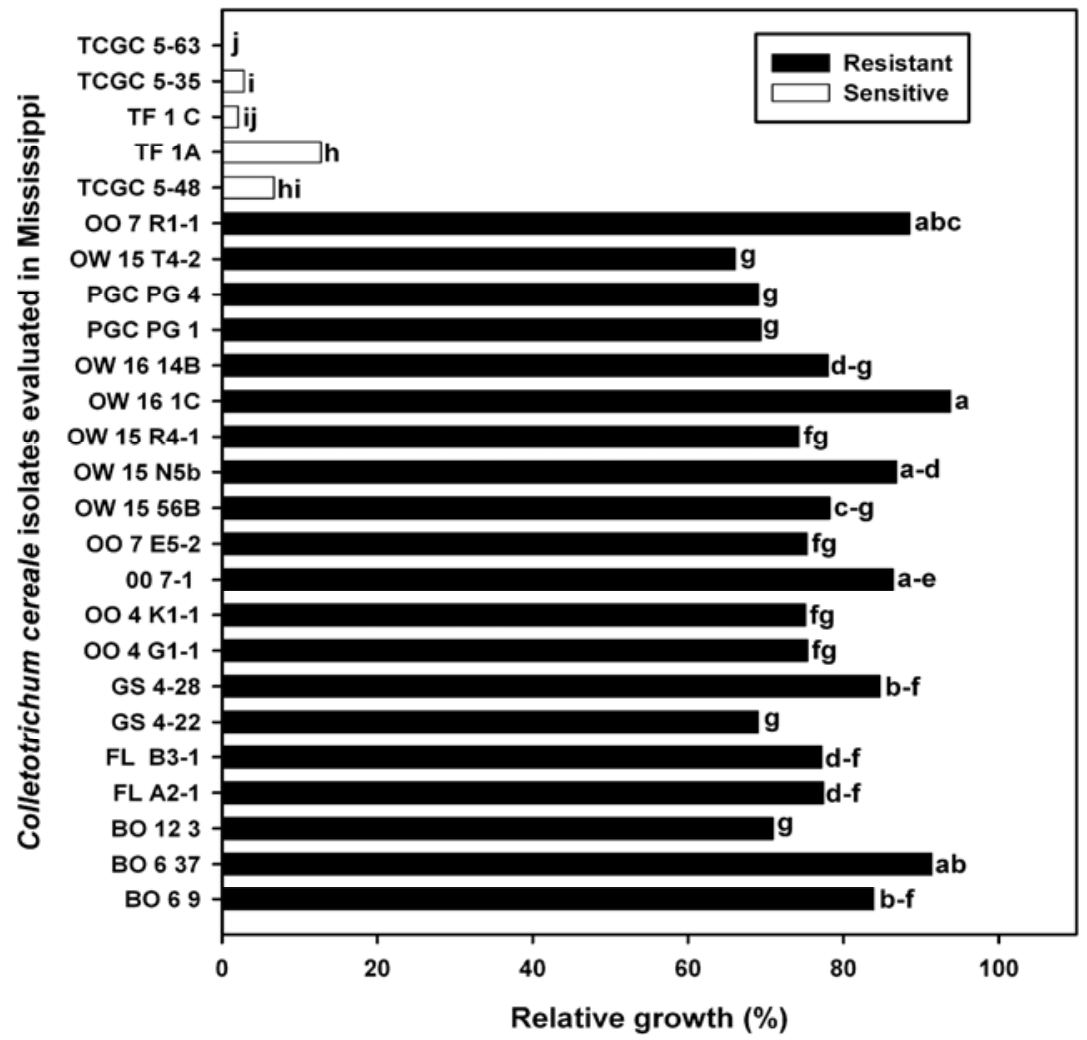

Fig. 1. Relative growth of select Colletotrichum cereale isolates evaluated in Mississippi with azoxystrobin at $8 \mu \mathrm{g} / \mathrm{ml}$. Sensitive isolates evaluated originated from annual bluegrass in California (TCGC 5-63, 5-35, and 5-48) or tall fescue in Mississippi (TF 1C and 1A). Percent relative growth values were arcsine transformed and analyzed in SAS using PROC GLIMMIX. Least-square means were used to separate significantly different relative growth means; bars with the same letter are not significantly different at $P=0.05$. 
percent identity using DNA Lasergene software. All isolates were sequenced twice.

Efficacy of QoI fungicides for anthracnose control in North Carolina. A field evaluation was conducted in 2006 on a creeping bentgrass, putting green $\mathrm{cv}$. Dominant, that was artificially inoculated with $C$. cereale isolates (ABR-1, $-3,-5,-7$, $-46,-48,-50$, and -52 ) exhibiting complete resistance to azoxystrobin in vitro (data not shown) prior to fungicide applications. The putting green had no prior history of anthracnose and symptoms were never observed prior to inoculation with $C$. $\mathrm{ce}$ reale isolates. Conidia were suspended in $1.6 \mathrm{~g}$ of PDA per liter, resulting in a final concentration of $9 \times 10^{3}$ conidia/ml. The inoculum was applied as a foliar suspension to the creeping bentgrass in the eve-

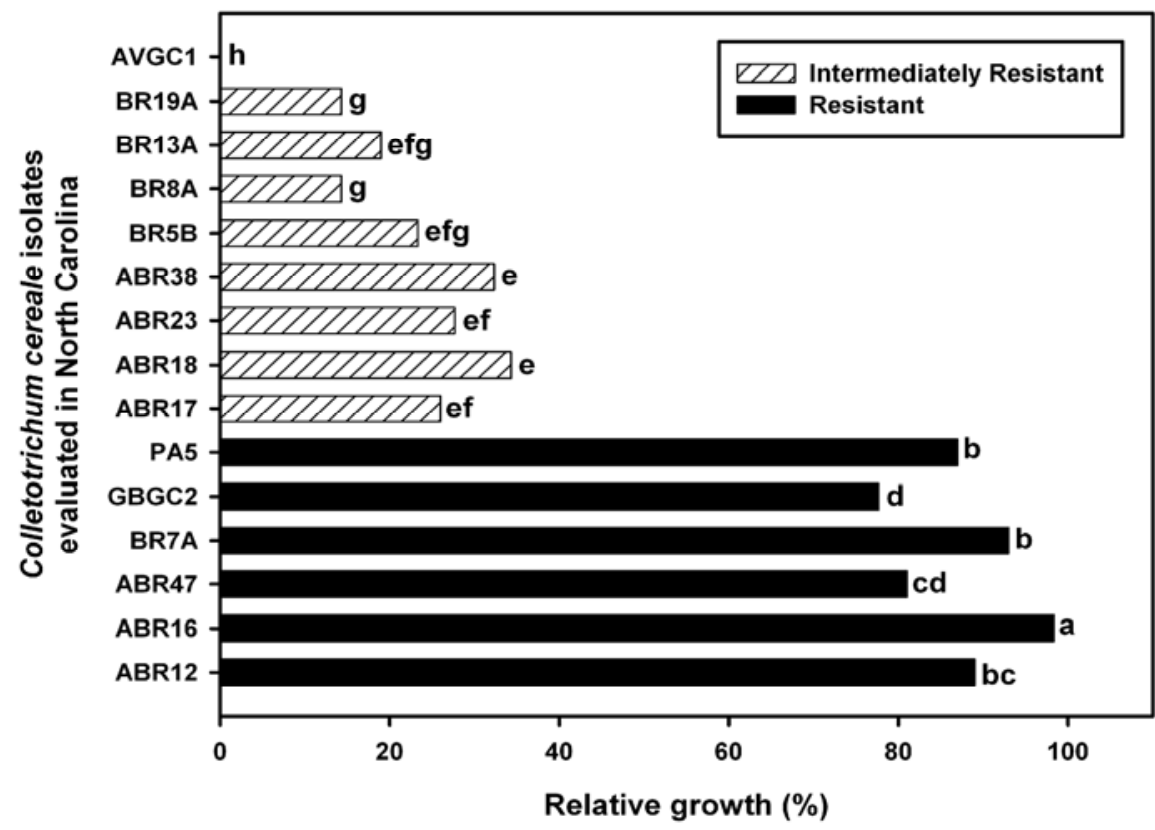

Fig. 2. Relative growth of select Colletotrichum cereale isolates evaluated in North Carolina with isolate AVGC1 exhibiting complete inhibition with azoxystrobin at $8 \mu \mathrm{g} / \mathrm{ml}$. Percent relative growth values were arcsine transformed and analyzed in SAS using PROC GLIMMIX. Least-square means were used to separate significantly different relative growth means; bars with the same letter are not significantly different at $P=0.05$.

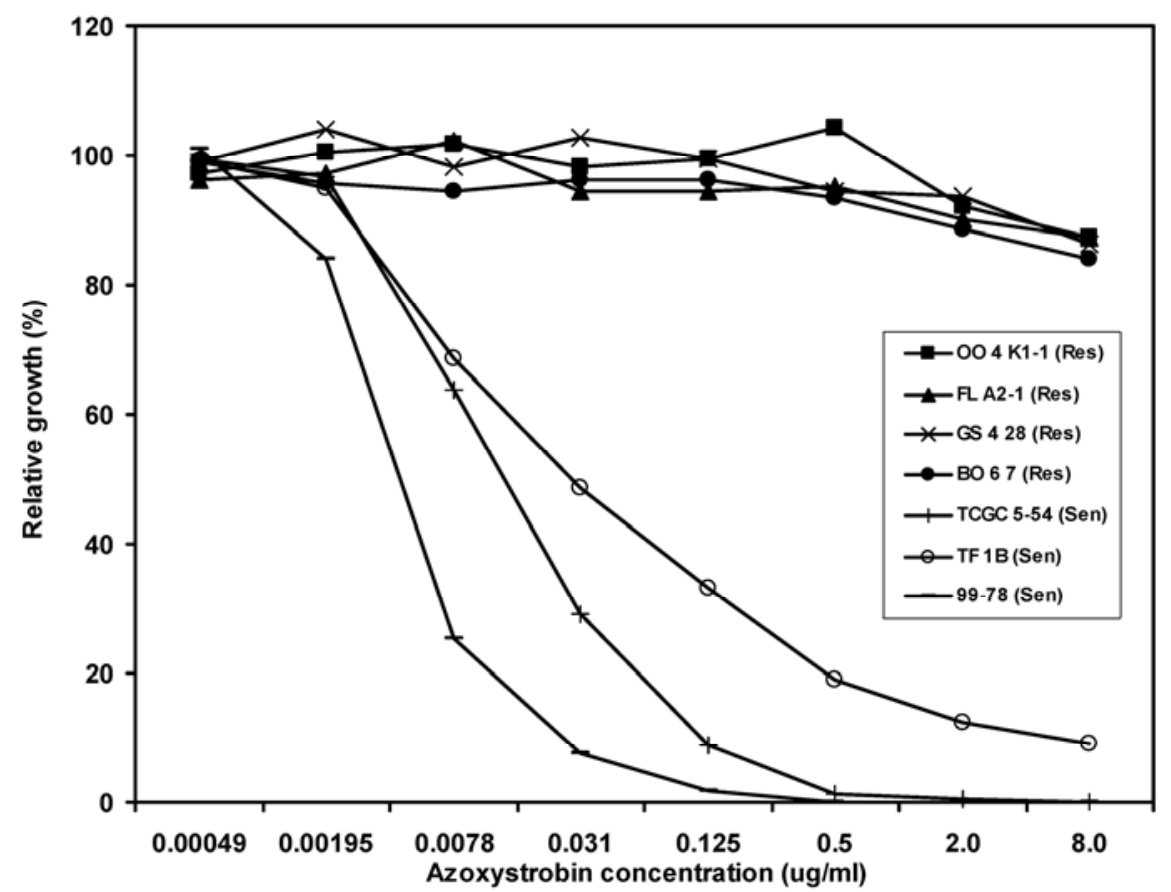

Fig. 3. Effect of azoxystrobin at different concentrations on radial growth of Colletotrichum cerealeresistant isolates from creeping bentgrass putting greens in Mississippi and Alabama compared with sensitive isolates from annual bluegrass (TCGC 5-54 and 99-78) or tall fescue (TF 1B). ning of 25 May using a $\mathrm{CO}_{2}$-powered boom sprayer at $276 \mathrm{kPa}$ with 8004 flat fan nozzles (TeeJet Technologies, Wheaton, IL) and calibrated to deliver water at 814 liters/ha. The study area was immediately irrigated with $2.5 \mathrm{~mm}$ of water.

The creeping bentgrass putting green was mowed, fertilized, and watered with a routine management schedule used to maintain golf course putting greens. Fungicide treatments and application rates are shown in Table 2. Fungicide treatments were applied as previously described for the foliar inoculum application, except that irrigation was not applied after the fungicide applications. Anthracnose incidence was determined by estimating the percent plot area exhibiting symptoms using a point-intersect method. Turfgrass quality, based on color, density, and uniformity, was determined visually on a scale of 1 to 9 ( $9=$ best; $6 \geq$ acceptable). The plot size was $1.0 \mathrm{~m}$ wide by $1.8 \mathrm{~m}$ long and treatments were arranged in a randomized complete block with four replications. Data were subjected to analysis of variance, PROC GLM, and means separation by a Waller-Duncan $k$-ratio $t$ test $(k=100)$.

\section{RESULTS}

In vitro sensitivity evaluations. Three azoxystrobin sensitivity levels were identified among $C$. cereale isolates (Table 1). A resistant group composed of $81 \%$ of all isolates had relative growth that ranged from 55 to $119 \%$ of the untreated control with a mean of $81 \%$ at the discriminatory dose (22) of azoxystrobin at $8 \mu \mathrm{g} / \mathrm{ml}$. Of the $C$. cereale isolates tested, $5 \%$ exhibited intermediate resistance and showed inhibition at the discriminatory dose $(8 \mu \mathrm{g} / \mathrm{ml})$, with relative growth ranging from 14 to $34 \%$ with a mean of $23 \%$; however, limited inhibition was observed with azoxystrobin at $0.031 \mu \mathrm{g} / \mathrm{ml}$, with relative growth ranging from 93 to $109 \%$ of the untreated control and a mean of $101 \%$. Sensitive isolates exhibited greater inhibition at both concentrations, with relative growth ranging from 0 to $75 \%$ and a mean of $44 \%$ for azoxystrobin at $0.031 \mu \mathrm{g} / \mathrm{ml}$ and 0 to $25 \%$ with a mean of $4 \%$ for azoxystrobin at $8 \mu \mathrm{g} / \mathrm{ml}$.

Resistant $C$. cereale isolates evaluated in Mississippi had significantly greater mean relative growth with azoxystrobin at 8 $\mu \mathrm{g} / \mathrm{ml}$ compared with sensitive isolates (Fig. 1). Relative growth of resistant isolates was $74 \%$ greater than that of sensitive isolates. Significant differences in relative growth were observed among resistant isolates; however, all resistant isolates had significantly greater relative growth than the sensitive isolates (Fig. 1).

Of the isolates evaluated in North Carolina, the sensitive isolate, AVGC1, exhibited no growth and was significantly different from all other $C$. cereale isolates with azoxystrobin at $8 \mu \mathrm{g} / \mathrm{ml}$ (Fig. 2). The remaining isolates exhibited significantly 
different relative growth, resulting in isolates classified as resistant or intermediately resistant. The relative growth of intermediately resistant isolates was $65 \%$ less than that of resistant isolates (Fig. 2). Differences in relative growth were observed within the resistant group; however, all isolates classified as resistant had significantly greater relative growth than intermediately resistant or sensitive isolates (Fig. 2).

$\mathrm{EC}_{50}$ values for resistant isolates collected in Alabama and Mississippi were considered to be greater than $8 \mu \mathrm{g} / \mathrm{ml}$ azoxystrobin due to the lack of mycelial growth inhibition at the discriminatory dose. Sixteen sensitive isolates had $\mathrm{EC}_{50}$ values for azoxystrobin ranging from 0.003 to $1.079 \mu \mathrm{g} / \mathrm{ml}$ with a mean of 0.130 $\mu \mathrm{g} / \mathrm{ml}$. Relative growth of resistant isolates was slightly inhibited at high concentrations, which was in contrast to sensitive isolates that were progressively more inhibited as azoxystrobin concentrations increased (Fig. 3).

Characterization of cytochrome b gene sequences. Nucleotide sequences of the cytochrome $b$ gene were obtained for $40 C$. cereale isolates exhibiting different levels of sensitivity to azoxystrobin. The cytochrome $b$ sequences corresponded to amino acid residues 98 to $170(2,29)$, specifically containing residues 129 and 143 that have been previously associated with QoI resistance $(1,2,12,16,29)$. In all, 65\% of the $C$. cereale isolates sequenced were classified as resistant in vitro and had a transversion point mutation from guanine to cytosine resulting in the G143A change. The $C$. cereale isolates classified as intermediately resistant had a transversion point mutation from cytosine to guanine resulting in the F129L change, whereas the sensitive isolates retained phenylalanine and glycine at positions 129 and 143, respectively (Table 3). Percent identity for all the $C$. cereale isolates ranged from 94 to $99 \%$ compared with the GenBank reference sequence AY285743.

Twenty C. cereale isolates from Alabama and Mississippi identified as azoxystrobin-resistant based on in vitro bioassays expressed the G143A substitution. In contrast, the sensitive isolates from California and Mississippi did not exhibit any amino acid substitutions (Table 3). Six resistant $C$. cereale isolates collected from creeping bentgrass in the eastern transition zone had the G143A substitution, whereas the F129L substitution was identified in eight isolates from annual bluegrass in North Carolina expressing intermediate resistance (Table 3). The sensitive isolate from North Carolina had no amino acid substitutions at either location (Table 3).

Efficacy of QoI fungicides for anthracnose control in North Carolina. In July 2006 , temperatures $\geq 32^{\circ} \mathrm{C}$ coupled with relative humidity $\geq 85 \%$ induced heat stress in the artificially inoculated creeping bentgrass putting green, predisposing the plants to infection. By early August, symptoms of anthracnose were evident, and microscopic observations confirmed foliar infection by $C$. cereale. Fungicide treatments were applied biweekly beginning 29 June 2006 and treatment differences were observed on 6 August. The three QoI fungicides applied alone were not effective for controlling anthracnose in creeping bentgrass previously inoculated with azoxystrobin-resistant $C$. cereale isolates, except for fluoxastrobin at the low rate (Table 4). Anthracnose incidence in thiophanate-methyl-treated plots was similar to the QoI fungicide treatments and untreated control. The greatest reduction in anthracnose incidence occurred in plots treated with fluoxastrobin tank mixed or alternated with propiconazole; however, anthracnose incidence was similar in plots treated with propiconazole alone. Fosetyl$\mathrm{Al}$ alone or tank mixed with chlorothalonil reduced anthracnose incidence compared with azoxystrobin and the untreated control (Table 4).

Turfgrass quality observed on 6 August was improved in creeping bentgrass plots treated with fluoxastrobin tank mixed with another non-QoI fungicide (Table 4). Azoxystrobin, pyraclostrobin, or both rates of fluoxastrobin did not improve turfgrass quality compared with the untreated control. Fosetyl-Al tank mixed with chlorothalonil was the only fungicide treatment that provided acceptable turfgrass quality on 6 August. Thiophanate-methyl and chlorothalonil had the lowest turfgrass quality rating of 2.8 (Table 4 ).

\section{DISCUSSION}

Creeping bentgrass and annual bluegrass putting greens in the southern United States and eastern transition zone that were sampled in this study were dominated by azoxystrobin-resistant isolates. Historically, applications of QoIs to manage turfgrass diseases at the locations where $C$. cereale isolates were collected have occurred with great frequency. Based on the use of QoIs, these results were not unexpected considering anecdotal evidence from superintendents and reports of $C$. cereale resistance occurring at other locations $(2,6,8,10,17-19,25,26,29)$. However, this was the first documentation of azox-

Table 3. Molecular characterization of Colletotrichum cereale isolates from turfgrasses throughout the southern United States, eastern transition zone, and California

\begin{tabular}{|c|c|c|c|c|}
\hline \multirow[b]{2}{*}{ Isolate } & \multirow[b]{2}{*}{ Accession no. } & \multirow[b]{2}{*}{ Location of analysis } & \multicolumn{2}{|c|}{ Amino acid position } \\
\hline & & & 129 & 143 \\
\hline BO 69 & FJ799953 & Mississippi & Phe & Ala \\
\hline BO 637 & FJ799954 & Mississippi & Phe & Ala \\
\hline BO 123 & FJ799955 & Mississippi & Phe & Ala \\
\hline FL A2-1 & FJ799956 & Mississippi & Phe & Ala \\
\hline FL B3-1 & FJ799957 & Mississippi & Phe & Ala \\
\hline GS 422 & FJ799958 & Mississippi & Phe & Ala \\
\hline GS 428 & FJ799959 & Mississippi & Phe & Ala \\
\hline OO 4 G1-1 & FJ799960 & Mississippi & Phe & Ala \\
\hline OO 4 K1-1 & FJ799961 & Mississippi & Phe & Ala \\
\hline OO 71 & FJ799962 & Mississippi & Phe & Ala \\
\hline OO 7 E5-1 & FJ799963 & Mississippi & Phe & Ala \\
\hline OO 7 R1-1 & FJ799964 & Mississippi & Phe & Ala \\
\hline OW $1556 b$ & FJ799966 & Mississippi & Phe & Ala \\
\hline OW 15 N5b & FJ799967 & Mississippi & Phe & Ala \\
\hline OW 15 R4-1 & FJ799968 & Mississippi & Phe & Ala \\
\hline OW 15 T4-2 & FJ799969 & Mississippi & Phe & Ala \\
\hline OW 16 1C & FJ799970 & Mississippi & Phe & Ala \\
\hline OW 16 14B & FJ799971 & Mississippi & Phe & Ala \\
\hline PGC PG 1 & FJ799972 & Mississippi & Phe & Ala \\
\hline PGC PG 4 & FJ799973 & Mississippi & Phe & Ala \\
\hline TCGC 5-35 & FJ799974 & Mississippi & Phe & Glu \\
\hline TCGC 5-48 & FJ799975 & Mississippi & Phe & Glu \\
\hline TCGC 5-63 & FJ799976 & Mississippi & Phe & Glu \\
\hline $\mathrm{TF} 1 \mathrm{~A}$ & FJ799977 & Mississippi & Phe & Glu \\
\hline TF $1 \mathrm{C}$ & FJ799978 & Mississippi & Phe & Glu \\
\hline ABR12 & GQ255954 & North Carolina & Phe & Ala \\
\hline ABR16 & GQ255955 & North Carolina & Phe & Ala \\
\hline ABR47 & GQ255960 & North Carolina & Phe & Ala \\
\hline BR7A & GQ255963 & North Carolina & Phe & Ala \\
\hline GBGC2 & GQ255967 & North Carolina & Phe & Ala \\
\hline PA5 & GQ255968 & North Carolina & Phe & Ala \\
\hline ABR17 & GQ255956 & North Carolina & Leu & Glu \\
\hline ABR18 & GQ255957 & North Carolina & Leu & Glu \\
\hline ABR23 & GQ255958 & North Carolina & Leu & Glu \\
\hline ABR38 & GQ255959 & North Carolina & Leu & Glu \\
\hline BR5B & GQ255962 & North Carolina & Leu & Glu \\
\hline BR8A & GQ255964 & North Carolina & Leu & Glu \\
\hline BR13A & GQ255965 & North Carolina & Leu & Glu \\
\hline BR19A & GQ255966 & North Carolina & Leu & Glu \\
\hline AVGC1 & GQ255961 & North Carolina & Phe & Glu \\
\hline
\end{tabular}


ystrobin resistance in $C$. cereale isolated from creeping bentgrass in the United States that was confirmed using molecular methods.

Differences in relative growth, based on in vitro bioassays, were evident when comparing sensitive, intermediate, and resistant $C$. cereale isolates at the two azoxystrobin concentrations. Isolates with intermediate resistance exhibited colony growth inhibition with azoxystrobin at 8 $\mu \mathrm{g} / \mathrm{ml}$ but were insensitive to azoxystrobin at $0.031 \mu \mathrm{g} / \mathrm{ml}$. Resistant isolates did not exhibit mycelial growth inhibition with azoxystrobin at $0.031 \mu \mathrm{g} / \mathrm{ml}$ and minimal inhibition was observed at $8 \mu \mathrm{g} / \mathrm{ml}$, which is consistent with previous reports of $C$. cereale resistance $(2,10,29)$.

C. cereale isolates collected from putting greens previously exposed to QoI fungicides exhibited either intermediate or complete resistance to azoxystrobin. Due to sampling size, these results may not be inclusive of all $C$. cereale isolates within the sampled putting greens. However, these results indicate the propensity of practical resistance within $C$. cereale populations on putting greens in the southern United States and eastern transition zone.

The phenotypic responses of $C$. cereale isolates observed in vitro were supported by sequences of the cytochrome $b$ gene. Deduced amino acid sequences revealed two separate substitutions that corresponded to the observed phenotypic responses in vitro. The most unique substitution was the F129L identified in C. cereale isolates exhibiting intermediate resistance to azoxystrobin. This is a first report of $C$. cereale isolates exhibiting this phenotypic response to azoxystrobin and characterized by the F129L substitution. The isolates expressing this substitution responded similarly to azoxystrobin, as did $P$. grisea and Alternaria solani Sorauer that expressed the F129L substitution and were classified as intermediately resistant in vitro $(16,20)$.

C. cereale isolates collected from creeping bentgrass and the remainder of the isolates collected from annual bluegrass in North Carolina expressed the G143A substitution. These isolates were characterized as resistant due to minimal in vitro growth inhibition observed with azoxystrobin at 8 $\mu \mathrm{g} / \mathrm{ml}$. These results are consistent with $C$. cereale isolates obtained from annual bluegrass putting greens expressing the G143A substitution in previous reports $(2,29)$

The fungicide evaluation conducted in North Carolina on a creeping bentgrass putting green with no prior history of anthracnose and subsequently artificially inoculated with azoxystrobin-resistant isolates indicated a phenotypic response similar to that observed by $C$. cereale isolates in azoxystrobin bioassays. The QoI fungicides did not successfully control anthracnose following inoculation with azoxystrobin-resistant isolates. These results are similar to other reports that indicate that QoI fungicides are not effective when azoxystrobin-resistant isolates cause anthracnose in creeping bentgrass putting greens (6-8).

Azoxystrobin, pyraclostrobin, and fluoxastrobin (high rate) applied alone were not effective for controlling anthracnose. The lower rate of fluoxastrobin applied alone, tank mixed, or alternated with propiconazole significantly reduced anthracnose incidence. The only treatments that resulted in the greatest reduction of anthracnose incidence were fosetyl-Al alone or tank mixed with chlorothalonil. However, this evaluation did illustrate improved efficacy of the QoI, fluoxastrobin, when applied in combination with another fungicide class; in this case, a demethylation inhibitor, to manage $C$. cereale exhibiting practical resistance to QoI fungicides (19). The potential for cross resistance among QoIs was also supported by the results of the fungicide evaluation and is consistent with other studies previously reported $(2,7,8,17,26$, 29,31).

The $C$. cereale isolates evaluated in this study also exhibited multiple resistance (5) due to their lack of sensitivity to thiophanate-methyl determined previously via in vitro analyses and amino acid substitutions identified in the $\beta$-tubulin 2 protein $(27,34)$. Multiple resistance is again supported in the fungicide evaluation where thiophanate-methyl did not successfully control anthracnose. The possibility of multiple resistance should raise the awareness of golf course superintendents to implement fungicide resistance management strategies, including reducing the frequency of at-risk fungicide applications, maintaining recommended rates, avoiding curative applications, and using integrated disease management programs (5). Cultural practices and management strategies

Table 4. Anthracnose incidence and turfgrass quality observed on 6 August 2006 resulting from a fungicide evaluation on a creeping bentgrass putting green inoculated with azoxystrobin-resistant Colletotrichum cereale isolates in North Carolina ${ }^{u}$

\begin{tabular}{|c|c|c|c|}
\hline Fungicide $^{v}$ & Rate (kg or liters of product/ha) & Anthracnose incidence $(\%)^{\mathrm{w}}$ & Turf quality $^{x}$ \\
\hline Thiophanate-methyl & 12.6 liters & 22 bcdef $^{y}$ & $2.8 \mathrm{f}$ \\
\hline Phosphoric acid & 17.6 liters & $29 \mathrm{ab}$ & 3.3 ef \\
\hline Chlorothalonil/thiophanate-methyl ${ }^{\mathrm{z}}$ & $17.6 \mathrm{~kg}$ & $16 \mathrm{cdefgh}$ & $3.5 \mathrm{def}$ \\
\hline Chlorothalonil/thiophanate-methyl ${ }^{\mathrm{z}}+$ phosphoric acid & $17.6 \mathrm{~kg}+17.6$ liters & 21 bcdefg & 4.5 bcde \\
\hline Azoxystrobin & $0.61 \mathrm{~kg}$ & $25 \mathrm{bcd}$ & $4.0 \mathrm{cdef}$ \\
\hline Fosetyl-Al & $12.2 \mathrm{~kg}$ & 12 fghij & $4.0 \mathrm{cdef}$ \\
\hline Propiconazole & 3.18 liters & 13 efghij & $3.8 \mathrm{def}$ \\
\hline Fluoxastrobin & 0.57 liter & 11 ghij & $3.8 \mathrm{def}$ \\
\hline Fluoxastrobin & 1.14 liter & 15 defghij & $4.0 \mathrm{cdef}$ \\
\hline Fluoxastrobin + propiconazole & 0.57 liter +3.18 liters & $4 \mathrm{ij}$ & $5.0 \mathrm{abcd}$ \\
\hline Fluoxastrobin + chlorothalonil & 0.57 liter $+5.5 \mathrm{~kg}$ & 14 defghij & 5.0 abcd \\
\hline Fluoxastrobin + polyoxin-D & 0.57 liter $+6.1 \mathrm{~kg}$ & 15 defghi & $5.0 \mathrm{abcd}$ \\
\hline Fluoxastrobin + propiconazole + potassium phosphate & 0.57 liter +3.18 liters +12.7 liters & 11 fghij & $5.5 \mathrm{abc}$ \\
\hline Fluoxastrobin followed by propiconazole & 0.57 liter followed by 3.18 liters & $8 \mathrm{hij}$ & $4.3 \mathrm{bcdef}$ \\
\hline Fluoxastrobin followed by polyoxin-D & 0.57 liter followed by $6.11 \mathrm{~kg}$ & $16 \mathrm{cdefgh}$ & $3.8 \mathrm{def}$ \\
\hline Fosetyl-Al + chlorothalonil & $12.2 \mathrm{~kg}+9.8 \mathrm{~kg}$ & 7 hij & $6.3 \mathrm{a}$ \\
\hline Chlorothalonil & $9.8 \mathrm{~kg}$ & $30 \mathrm{ab}$ & $2.8 \mathrm{f}$ \\
\hline Phosphoric acid + chlorothalonil & 17.6 liters $+9.8 \mathrm{~kg}$ & $29 \mathrm{ab}$ & $3.8 \mathrm{def}$ \\
\hline Pyraclostrobin & $1.5 \mathrm{~kg}$ & $15 \mathrm{cdefgh}$ & $3.5 \mathrm{def}$ \\
\hline Control (water) & $\ldots$ & 24 bcde & $3.3 \mathrm{ef}$ \\
\hline
\end{tabular}

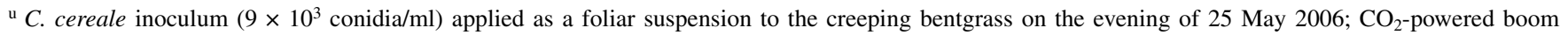
sprayer at $276 \mathrm{kPa} ; 8004$ flat fan nozzles, calibrated to deliver water at 814 liters/ha; irrigated with $2.5 \mathrm{~mm}$ of water.

$\checkmark$ Treatments applied in water equivalent to 814 liters/ha; 14-day spray interval; application dates 29 June, 13 and 27 July, and 10 and 23 August 2006.

${ }^{\text {w }}$ Anthracnose incidence determined by the percent surface area exhibiting anthracnose symptoms using a point-intersect method.

${ }^{x}$ Turf quality based on a visual rating scale of 1 to 9 scale, where $9=$ highest quality and $6=$ acceptable quality.

${ }^{y}$ Values represent means of four replications. Means within columns followed by the same letter are not significantly different according to the WallerDuncan $k$-ratio $t$ test $(k=100)$.

${ }^{\mathrm{z}}$ Prepackaged fungicide. 
such as mowing and rolling frequency, vertical mowing, plant growth regulator applications, and nitrogen fertility have been evaluated on annual bluegrass putting greens in the northeastern United States, resulting in reduced anthracnose severity $(13,14)$. These management strategies should be investigated on creeping bentgrass and annual bluegrass putting greens in the southern United States and eastern transition zone to determine which practices may best manage anthracnose in these regions.

The results of this research illustrate how widespread fungicide resistance has become in $C$. cereale infecting creeping bentgrass and annual bluegrass putting greens in the southern United States and eastern transition zone. These results also document the first F129L substitution in a species of Colletotrichum exhibiting intermediate resistance in vitro. The remainder of $C$. cereale isolates evaluated in this study had the G143A substitution and exhibited minimal sensitivity to azoxystrobin in vitro. The dominance of resistant $C$. cereale isolates was not expected at the initiation of this study; however, these results illustrate the shift from predominantly sensitive to resistant isolates on highly managed putting greens. Based on the findings of this research, future work should focus on fungicide resistance through a population and management perspective. If new single-site mode-ofaction fungicides are developed to control C. cereale, studies should be conducted to determine optimal timing and frequency of applications to minimize selection pressure and maximize the longevity of the new chemistry.

\section{ACKNOWLEDGMENTS}

We thank all of the golf course superintendents for access to their putting greens and student workers at Mississippi State University, the University of California, Riverside, and North Carolina State University turfgrass pathology labs for their assistance in the research project. Funding was provided in part by the Memphis-area Golf Course Superintendents Association and the Mississippi Agricultural and Forestry Experimental Station.

\section{LITERATURE CITED}

1. Avila-Adame, C., and Köller, W. 2003. Characterization of spontaneous mutants of Magnaporthe grisea expressing stable resistance to the Qo-inhibiting fungicide azoxystrobin. Curr. Genet. 42:332-338.

2. Avila-Adame, C., Olaya, G., and Köller, W. 2003. Characterization of Colletotrichum graminicola isolates resistant to strobilurinrelated QoI fungicides. Plant Dis. 87:14261431.

3. Backman, P. A., Landschoot, P. J., and Huff, D. R. 1999. Variation in pathogenicity, morphology, and RAPD marker profiles in Colleto- trichum graminicola from turfgrasses. Crop Sci. 39:1129-1335.

4. Bartlett, D. W., Clough, J. M., Godwin, J. R., Hall, A. A., Hamer, M., and Parr-Dobrzanki, B. 2002. The strobilurin fungicides. Pest Manage. Sci. 58:649-662.

5. Brent, K. J., and Hollomon, D. W. 2007. Fungicide resistance in crop pathogens: How can it be managed? FRAC Monogr. No. 1. Crop Life International, Brussels.

6. Burpee, L. L., Stephens, S. L., and MartinezEspinoza, A. D. 2004. Control of anthracnose caused by a benzimidazole- and QoI-resistant isolate of Colletotrichum graminicola, 2003. Fungic. Nematicide Tests 59:T016.

7. Burpee, L. L., Stephens, S. L., and MartinezEspinoza, A. D. 2004. Suppression of anthracnose caused by an isolate of Colletotrichum graminicola with dual fungicide resistance, 2003. Fungic. Nematicide Tests 59:T017.

8. Burpee, L. L., Stephens, S. L., and MartinezEspinoza, A. D. 2005. Control of anthracnose caused by an isolate of Colletotrichum graminicola exhibiting dual fungicide resistance, 2004. Fungic. Nematicide Tests 60: $\mathrm{T} 044$.

9. Couch, H. B. 2000. The Turfgrass Disease Handbook, 1st ed. Krieger Publishing Company, Malabar, FL.

10. Crouch, J. A., Clarke, B. B., and Hillman, B. I. 2005. Phylogenetic relationships and fungicide sensitivities of Colletotrichum graminicola isolates from turfgrass in North America. Int. Turfgrass Soc. Res. 10:186-195.

11. Crouch, J. A., Clarke, B. B., and Hillman, B. I. 2006. Unraveling evolutionary relationships among the divergent lineages of Colletotrichum causing anthracnose disease in turfgrass and corn. Phytopathology 96:46-60.

12. Fernández-Ortuño, D., Torés, J. A., de Vicente, A., and Pérez-García, A. 2008. Mechanisms of resistance to QoI fungicides in phytopathogenic fungi. Int. Microbiol. 11:1-9.

13. Inguagiato, J. C., Murphy, J. A., and Clarke, B. B. 2008. Anthracnose severity on annual bluegrass influenced by nitrogen fertilization, growth regulators, and verticutting. Crop Sci. 48:1595-1607.

14. Inguagiato, J. C., Murphy, J. A., and Clarke, B. B. 2009. Mowing and rolling strategies to manage anthracnose on annual bluegrass greens. Golf Course Manage. No. 5:111-116.

15. Khan, A., and Hsiang, T. 2003. The infection process of Colletotrichum graminicola and relative aggressiveness on four turfgrass species. Can. J. Microbiol. 49:433-442.

16. Kim, Y. S., Dixon, E. W., Vincelli, P., and Farman, M. L. 2003. Field resistance to strobilurin (QoI) fungicides in Pyricularia grisea caused by mutations in the mitochondrial cytochrome b gene. Phytopathology 93:891-900.

17. McCullough, M. D., and Wong, F. P. 2005. Evaluation of mid-season fungicide applications for the control of anthracnose on a mixed annual bluegrass and creeping bentgrass green in northern California, summer 2004. Fungic. Nematicide Tests 60:T056.

18. Milus, E. A., Richardson, M. D., Hensler, K. L., and Weight, C. T. 2002. Evaluations of fungicides for control of anthracnose on bentgrass putting greens, 1998. Fungic. Nematicide Tests 57:T07.

19. Mitkowski, N. A., Madeiras, A. M., Chaves, A., and Wick, A. 2009. Fungicide sensitivity of Colletotrichum cereale isolated from turf- grasses in the northeastern United States. Online. Applied Turf. Sci. doi:10.1094/ATS 2009-0917-01-RS.

20. Pasche, J. S., Piche, L. M., and Gudmestad, N. C. 2005. Effect of the F129L mutation in Alternaria solani on fungicides affecting mitochondrial respiration. Plant Dis. 89:269-278.

21. Pscheidt, J. W. 2009. Fungicide theory of use and mode of action. Online. http://plant-dis ease.ippc.orst.edu/articles.cfm?article_id=12.

22. Russel, P. E. 2004. Sensitivity baselines in fungicide resistance research and management. FRAC Monogr. No. 3. Crop Life International, Brussels.

23. Sauter, H., Steglich, W., and Anke, T. 1999 Strobilurins: evolution of a new class of active substances. Angew. Chem. Int. Ed. 38:13281349

24. Smiley, R. W., Dernoeden, P. H., and Clarke, B. B. 2005. Compendium of Turfgrass Diseases, 3rd ed. American Phytopathological Society, St. Paul, MN.

25. Tredway, L. P. 2006. Evaluation of fungicides for prevention of anthracnose foliar blight, 2005. Fungic. Nematicide Tests 61:T038.

26. Tredway, L. P., and Soika, M. D. 2008. Impact of fungicides applied for brown patch control on anthracnose development in creeping bentgrass, 2007. Plant Dis. Manage. Rep. 2:T013.

27. Tredway, L. P., Soika, M. D., and Bunting, M. L. 2008. Fungicide sensitivity in North Carolina populations of Colletotrichum cereale and molecular characterization of benzimidazoleand QoI-insensitive strains. (Abstr.) Phytopathology 98:S159.

28. Vincelli, P., and Dixon, E. 2002. Resistance to QoI (strobilurin-like) fungicides in isolates of Pyricularia grisea from perennial ryegrass. Plant Dis. 86:235-240.

29. Wong, F. P., Midland, S. L., and de la Cerda, K. A. 2007. Occurrence and distribution of QoI-resistant isolates of Colletotrichum cereale from annual bluegrass in California. Plant Dis. 91:1536-1546.

30. Wong, F. P., Rios, J. C., and Ries, S. B. 2007. Evaluation of fungicides for the control of anthracnose in southern California, 2006. Plant Dis. Manage. Rep. 1:T063.

31. Wong, F. P., Rios, J. C., and Ries, S. B. 2007. Evaluations of fungicides for the curative control of anthracnose in southern California, 2005. Plant Dis. Manage. Rep. 1:T064.

32. Young, J. R. 2009. Identification of strobilurin and benzimidazole resistance in Colletotrichum cereale isolates causing anthracnose on creeping bentgrass putting greens in Mississippi and Alabama. M.Sc. thesis, Mississippi State University, Mississippi State.

33. Young, J. R., Tomaso-Peterson, M., and Crouch, J. A. 2008. First report of Colletotrichum cereale causing anthracnose foliar blight of creeping bentgrass in Mississippi and Alabama. Plant Dis. 92:1475.

34. Young, J. R., Tomaso-Peterson, M., de la Cerda, K., and Wong, F. P. 2010. Two mutations in $\beta$-tubulin 2 gene associated with thiophanate-methyl resistance in Colletotrichum cereale isolates from creeping bentgrass in Mississippi and Alabama. Plant Dis. 94:207212.

35. Ziogas, B. N., Baldwin, B. C., and Young, J. E. 1997. Alternative respiration: A biochemical mechanism of resistance to azoxystrobin (ICIA 5504) in Septoria tritici. Pestic. Sci. 50:28-34. 